\title{
5. CRETACEOUS FORAMINIFERS FROM DEEP SEA DRILLING PROJECT SITE 612, NORTHWEST ATLANTIC OCEAN ${ }^{1}$
}

\author{
Malcolm B. Hart, Plymouth Polytechnic ${ }^{2}$
}

\begin{abstract}
Site 612, located some $100 \mathrm{~km}$ southeast of Atlantic City in the northwest Atlantic Ocean, was cored to a total depth of $675.3 \mathrm{~m}$ below seafloor. The final $114.96 \mathrm{~m}$ recovered an Upper Cretaceous succession that can be assigned to the late Campanian and early Maestrichtian. The dark mudstones of Campanian age contain an impoverished fauna of planktonic foraminifers, while the paler, nannofossil chalks of Maestrichtian age contain a typically diverse planktonic fauna. The environment represented by the Campanian fauna indicates the presence of slightly anoxic water in the vicinity of the New Jersey Slope at that time.
\end{abstract}

\section{INTRODUCTION}

Site 612, drilled during DSDP Leg 95 , is located on the middle part of the New Jersey Slope, some $100 \mathrm{~km}$ southeast of Atlantic City (Fig. 1). This site and the others on Leg 95 were designed to complement Sites 603, 604, and 605 (drilled during Leg 93) of the "New Jersey Transect" (Poag, 1985). The area has been intensively surveyed by the United States Geological Survey (U.S.G.S.) and the Bundesanstalt für Geowissenschaften und Rohstoffe (BRG), together with several other oceanographic institutions. Site 612 was located approximately on U.S.G.S. Line 25 in order for the sediments recovered to calibrate this important seismic data set. Site 612 was not intended to core any great distance into the Cretaceous sedimentary pile, but the short succession recovered has proven to be of great value.

The Cretaceous succession is divisible into two distinct lithologic units, with a marked erosional hiatus (Fig. 2) between them. The lowest part of the succession, of late Campanian age, comprises $27.8 \mathrm{~m}$ of black to gray, foraminifer or nannofossil chalks, mudstones, and shales. The dark color is attributed to the abundance of organic matter; the highest total organic carbon (TOC) value is $2.68 \%$. In the slide preparations for the dinoflagellate investigation (Tocher, this volume) large, matted clumps of dinoflagellates were seen in the majority of samples from this level.

The overlying $79.26 \mathrm{~m}$ of sediment is a gray, marly, intensely bioturbated foraminifer-nannofossil chalk. This unit is assigned to the Maestrichtian, but the foraminifers do not define any more than the lowest part of that stage.

\section{METHODOLOGY}

The samples were prepared using standard foraminiferal preparation methods. Samples were disaggregated gently using very dilute hy-

\footnotetext{
${ }^{1}$ Poag, C. W., Watts, A. B., et al., Init. Repts. DSDP, 95: Washington (U.S. Govt. Printing Office).

2 Address: Department of Geological Sciences, Plymouth Polytechnic, Drake Circus, Plymouth PL4 8AA, Devon, United Kingdom.
}

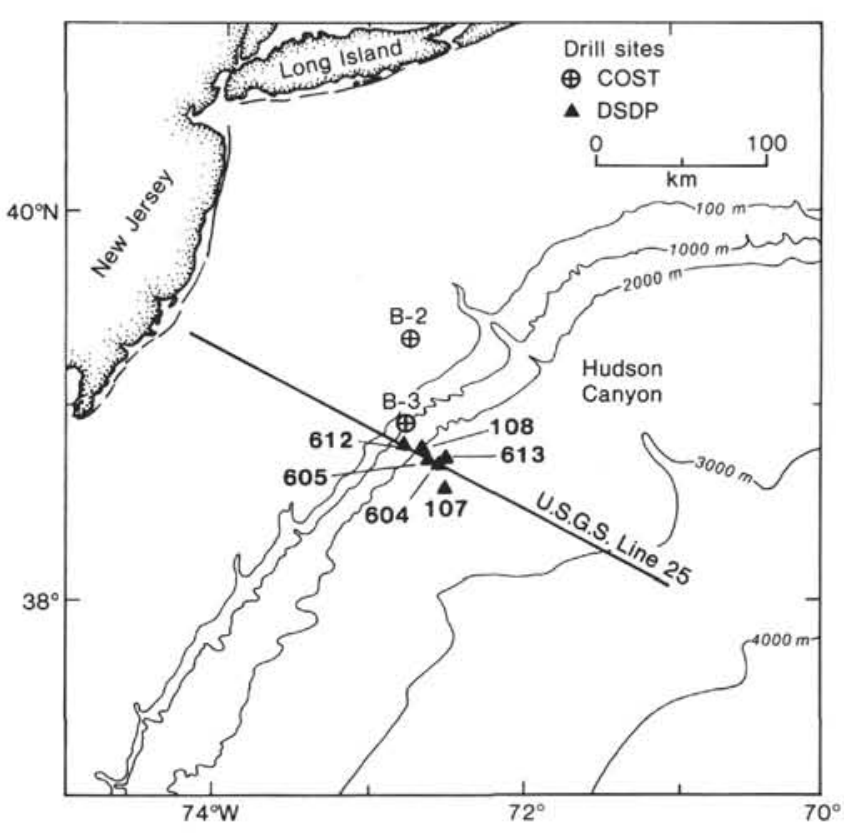

Figure 1. Locality map for DSDP Site 612.

drogen peroxide and wet sieved on $75-\mu \mathrm{m}$ mesh. When dried, the samples were inspected in the following size fractions; $>500 \mu \mathrm{m}, 500-250$ $\mu \mathrm{m}, 250-125 \mu \mathrm{m}$ and $125-75 \mu \mathrm{m}$. Faunal counts were made on the $500-$ $250 \mu \mathrm{m}$ size fractions, as this normally includes the greatest number of adult individuals and has the advantage of ease of study (see Poag and Low, this volume for an analysis of the finer size fractions). Full species lists were compiled but only taxa occurring in a number of samples have been included in this account. The only exceptions to this rule are those species known to have a proven stratigraphic value. Some typical examples of the fauna (and its preservation) are shown in Plate 1.

\section{PLANKTONIC FORAMINIFERS}

A total of 29 species of planktonic foraminifers were recorded (Table 1), many of which are long-ranging taxa of limited stratigraphic value. Preservation is poor to quite bad, and the specimens from the interval assigned to the Campanian are fragmented and badly corroded. The overlying Maestrichtian material is generally better preserved and some samples are in an exceptionally good condition. Identifications were largely based on the work 

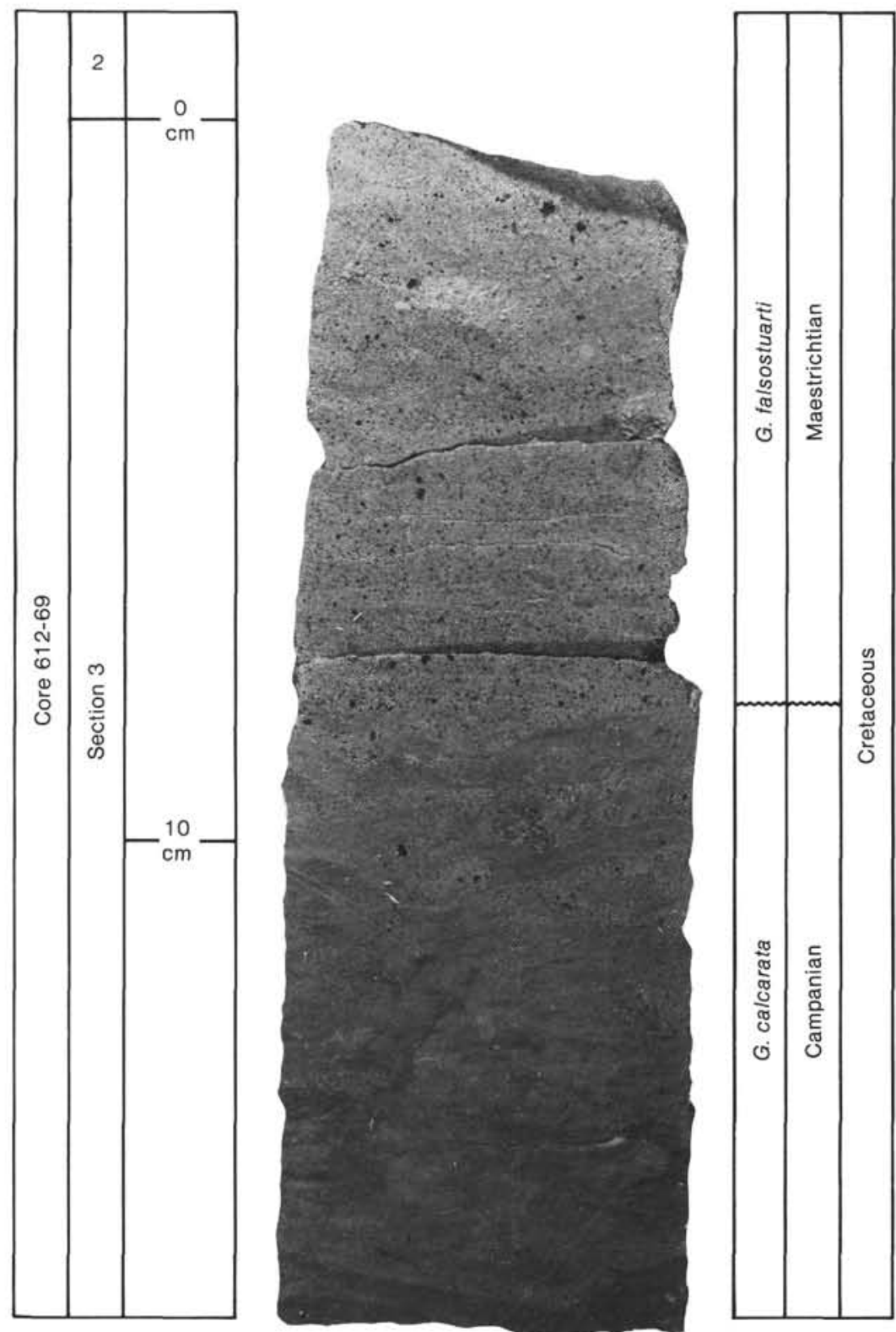

Figure 2. The Campanian/Maestrichtian boundary in Sample 612-69-3, $8 \mathrm{~cm}$. This level is intensely bioturbated, as is the whole of the Maestrichtian succession.

of Robaszynski et al. (1984), Smith and Pessagno (1973), and Pessagno (1967). The planktonic foraminifers cannot be used to identify precisely the interval represented by the hiatus (but see nannofossil information in Site 612 , chapter, this volume) seen at the Campanian/Maestrichtian boundary, nor have I found any specimens of Gansserina gansseri (Bolli), the presence of which would indicate a middle Maestrichtian age for the succession. However, Poag and Low (this volume), who also examined the finer size fractions, report the presence of (probably juvenile) G. gansseri in Sample 612-69-3, 4-7 cm. Only a few specimens of the early Maestrichtian zonal indicator, Globotruncana falsostuarti Sigal, were found, while in the late Campanian only one broken specimen Globotruncanita cf. calcarata (Cushman) was recorded. Typical late Campanian species such as Globotruncana bulloides Vogler, Globotruncana linneiana (d'Orbigny), Globotruncana arca (Cushman), and Rosita fornicata (Plummer) also range through into the early Maestrichtian. The more distinctively Maestrichtian species such as Globotruncanella havanensis (Voorwijk), Planoglobulina multicamerata de Klasz, Globotruncana aegyptiaca Nakkady, and Rugoglobigerina milamensis Smith and Pessagno appear gradually in the higher levels of the Site 612 succession. One or two of the ranges recorded here are at variance with the information provided by Robaszynski et al. (1984). The most dramatic of these discrepancies appear to be the very distinctive planoconvex specimens referable to Globotruncanita $\mathrm{cf}$. angulata Tilev, which have been recorded throughout the Cretaceous succession at Site 612 but for which Robaszynski et al. would only claim a middle and late Maestrichtian 
Table 1. The distribution of planktonic foraminifers in the Cretaceous succession of Site 612 .

\begin{tabular}{|c|c|c|c|c|c|c|c|c|c|c|c|c|c|c|c|c|c|c|c|c|c|c|c|c|c|c|c|c|c|c|}
\hline $\begin{array}{c}\text { Sample } \\
\text { (interval in cm) }\end{array}$ & 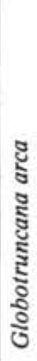 & 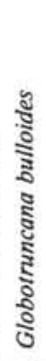 & 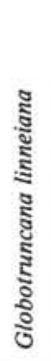 & 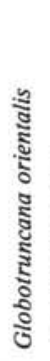 & 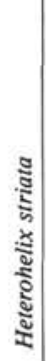 & 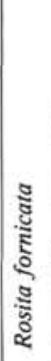 & 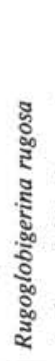 & 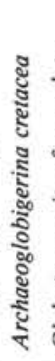 & 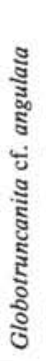 & 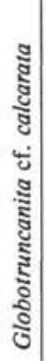 & 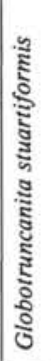 & 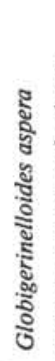 & 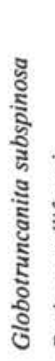 & 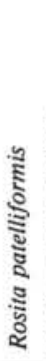 & 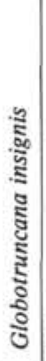 & 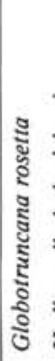 & 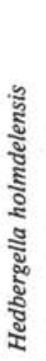 & 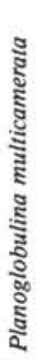 & 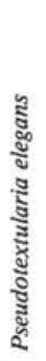 & 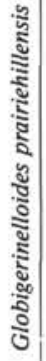 & 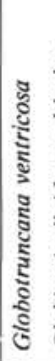 & 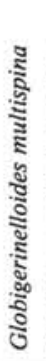 & 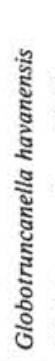 & 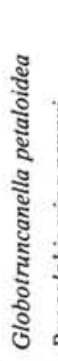 & 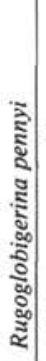 & 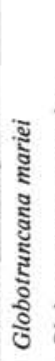 & 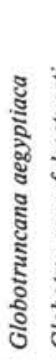 & 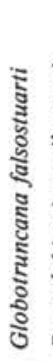 & 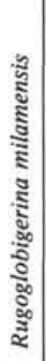 & Age \\
\hline $\begin{array}{l}612-61-4,30-32 \\
612-61, C C \\
612-62, C C \\
612-63, C C \\
612-64-2,30-32 \\
612-65, C C \\
612-66, C C \\
612-67, C C \\
612-68, C C\end{array}$ & $\begin{array}{l}\mathrm{x} \\
\mathrm{x} \\
\mathrm{x} \\
\mathrm{x} \\
\mathrm{x}\end{array}$ & $\begin{array}{l}\mathrm{x} \\
\mathrm{x} \\
\mathrm{x} \\
\mathrm{x}\end{array}$ & $\mathrm{x}$ & $\begin{array}{l}x \\
x\end{array}$ & $\begin{array}{l}\mathrm{x} \\
\mathrm{x}\end{array}$ & $\begin{array}{l}\mathrm{x} \\
\mathrm{x} \\
\mathrm{x} \\
\mathrm{x} \\
\mathrm{x} \\
\mathrm{x} \\
\mathrm{x}\end{array}$ & $\begin{array}{l}x \\
x\end{array}$ & $\mathrm{x}$ & $\begin{array}{l}\mathrm{x} \\
\mathrm{x}\end{array}$ & & $\mathrm{x}$ & $\begin{array}{l}x \\
x\end{array}$ & & $\begin{array}{l}x \\
x \\
x\end{array}$ & $\begin{array}{l}x \\
x\end{array}$ & $\mathrm{x}$ & $\begin{array}{l}\mathrm{x} \\
\mathrm{x}\end{array}$ & $\begin{array}{l}x \\
x \\
x\end{array}$ & $\begin{array}{l}x \\
x \\
x\end{array}$ & $\begin{array}{l}x \\
x \\
x\end{array}$ & $\begin{array}{l}x \\
x \\
x \\
x \\
x \\
x\end{array}$ & $\begin{array}{l}x \\
x \\
x\end{array}$ & $\begin{array}{l}\mathrm{x} \\
\mathrm{x}\end{array}$ & $\begin{array}{l}\mathrm{x} \\
\mathrm{x} \\
\mathrm{x} \\
\mathrm{x}\end{array}$ & $x$ & $\begin{array}{l}x \\
x\end{array}$ & $\mathbf{x}$ & $\mathrm{x}$ & $\mathrm{x}$ & Maestrichtian \\
\hline $\begin{array}{l}612-69, \mathrm{CC} \\
612-70, \mathrm{CC} \\
612-71, \mathrm{CC} \\
612-72, \mathrm{CC}\end{array}$ & $\begin{array}{l}\mathrm{x} \\
\mathrm{x}\end{array}$ & $\begin{array}{l}x \\
x \\
x \\
x\end{array}$ & $\begin{array}{l}\mathrm{x} \\
\mathrm{x} \\
\mathrm{x} \\
\mathrm{x}\end{array}$ & $\begin{array}{l}x \\
x \\
x \\
x\end{array}$ & $\begin{array}{l}\mathrm{x} \\
\mathrm{x} \\
\mathrm{x} \\
\mathrm{x}\end{array}$ & $\begin{array}{l}x \\
x \\
x \\
x\end{array}$ & $\mathrm{x}$ & $\begin{array}{l}x \\
x\end{array}$ & $\begin{array}{l}x \\
x \\
x\end{array}$ & $\mathrm{x}$ & $\begin{array}{l}x \\
x\end{array}$ & $\mathrm{x}$ & $\mathrm{x}$ & $\mathrm{x}$ & & & & & & & & & & & & & & & & Campanian \\
\hline
\end{tabular}

range. The full list of species recorded in Table 1 is as follows:

Archaeoglobigerina cretacea (d'Orbigny) = Globigerina cretacea d'Orbigny, 1840, p. 34, pl. 3, figs. 12-14.

Globigerinelloides aspera (Ehrenberg) $=$ Phanerostomum asperum Ehrenberg, 1854, p. 23, pl. 30, fig. 26.

Globigerinelloides prairiehillensis Pessagno, 1967, pp. 277-278, pl. 60 , figs. $2-3$ pl. 83 , fig. 1 , pl. 90 , figs. $1-2$, pl. 97 , figs. 3,4 ).

Globigerinelloides multispina (Lalicker) $=$ Biglobigerinella multispina Lalicker, 1948, p. 5, pl. 92, figs. 1-3.

Globotruncana aegyptiaca Nakkady, 1950, p. 690, pl. 80, fig. 20.

Globotruncana arca $($ Cushman) $=$ Pulvinulina arca Cushman, 1926, p. 23 , pl. 3, fig. 1.

Globotruncana bulloides Vogler, 1941, p. 287, pl. 23, figs. 32-39.

Globotruncana falsostuarti Sigal, 1952, p. 43, t. fig. 46.

Globotruncana insignis Gandolfi, 1955, p. 67, pl. 6, fig. 2a-c.

Globotruncana linneiana (d'Orbigny) = Rosalina linneiana d'Orbigny, 1839 , p. 101 , pl. 5, figs. 10-12.

Globotruncana mariei Banner and Blow, 1960; type figure is Globotruncana cretacea Cushman, 1938, pl. 11, fig. 6a-c.

Globotruncana orientalis El Naggar, 1966, p. 125, pl. 12, fig. 4a-d.

Globotruncana rosetta (Carsey) = Globigerina rosetta Carsey, 1926, p. 44 , pl. 5, fig. 3a-b.

Globotruncana ventricosa White, 1928, p. 284, pl. 38, fig. 5a-c.

Globotruncanella havanensis (Voorwijk) $=$ Globotruncana havanensis Voorwijk, 1937, p. 195, pl. 1, figs. 25, 26, 29.

Globotruncanella petaloidea Gandolfi subsp. petaloidea Gandolfi, 1955 , p. 52 , pl. 3, fig. 13a-c.

Globotruncanita $\mathrm{cf}$. angulata (Tilev) = Globotruncana lugeoni Tilev var. angulata Tilev, 1951, p. 46, pl. 3, fig. 1a-c, fig. 13a-c.

Globotruncanita cf. calcarata $($ Cushman $)=$ Globotruncana calcarata Cushman, 1927, p. 115, pl. 23, fig. 10a-b.

Globotrunita stuartiformis (Dalbiez) = Globotruncana (Globotruncana) elevata Brotzen subsp. stuartiformis Dalbiez, 1955, p. 169, t. fig. 10a-c.

Globotruncanita subspinosa $($ Pessagno $)=$ Globotruncana $($ Globotruncana) subspinosa Pessagno, 1960, p. 101, pl. 1, figs. 4-6.

Hedbergella holmdelensis Olsson, 1964, p. 160, pl. 1, fig. 2a-c.

Heterohelix striata (Ehrenberg) = Textularia striata Ehrenberg, 1840, p. 135 , pl. 4 , figs. $1-3$, not 9 .

Planoglobulina multicamerata de Klasz, 1953, p. 230, pl. 5, fig. 1a-b. Pseuotextularia elegans $($ Rzehak $)=$ Cuneolina elegans Rzehak, 1891, p. 4.

Rosita fornicata (Plummer) = Globotruncana fornicata Plummer, 1931, p. 130 , pl. 13, fig. 4a-c.
Rosita patelliformis (Gandolfi) = Globotruncana (Globotruncana) contusa (Cushman) subsp. patelliformis Gandolfi, 1955, p. 54, pl. 4 , fig. 2a-c.

Rugoglobigerina milamensis Smith and Pessagno, 1973, p. 56, pl. 24, figs. 4-7.

Rugogolbigerina pennyi Brönnimann, 1952, p. 34, pl. 4, figs. 1-3.

Rugoglobigerina rugosa (Plummer) = Globigerina rugosa Plummer, 1926 , p. 38 , pl. 2 , fig. 10 a.

\section{BENTHIC FORAMINIFERS}

The benthic foraminifers are well represented, especially in the late Campanian sediments. In the overlying Maestrichtian strata, ranges become difficult to establish as the small sample size, coupled with the reduced benthic faunas, provides a few individuals for study. There is an extensive literature on Cretaceous benthic foraminifers but the following provided all of the required information: Olsson and Nyong (1984), Nyong and Olsson (1984), Sliter (1968), Hart et al. (1981), Bailey (1978), and Swiecicki (1980). There are some significant differences in taxonomic usage between American and European workers, except for certain groups (e.g., Bolivinoides) of proven stratigraphic value. It is clear from this investigation that European names can, in many cases, be applied to the fauna under discussion, but in this limited study there has not been sufficient time for a full European vs. American comparison. Nearly all the recorded species (Table 2) are well known in northwest Europe, with clearly defined stratigraphical ranges (see Hart et al., 1981). It is probable, however, that such ranges may have been slightly different in the Baltimore Canyon Trough (allowing for migration times), although in some cases there appears to be no difference. The species of Neoflabellina, Bolivinoides, Stensioina, Eponides, and Osangularia all seem to be in agreement with their known ranges in the U.K., although some genera (e.g., Globorotalites) appear to have a slightly different range. Gavelinella monterelensis (Marie) still appears to 
Table 2. The distribution of benthic foraminifers in the Cretaceous succession of Site 612 .

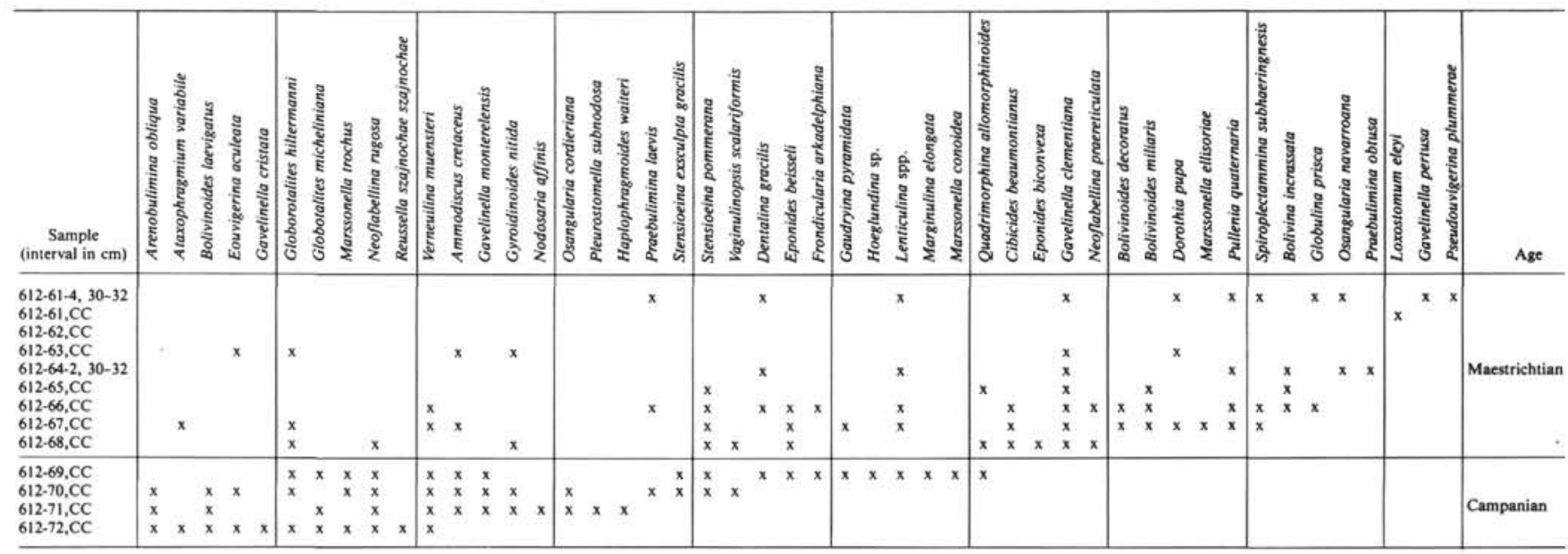

be a distinctive late Campanian species while Bolivinoides laevigatus Marie, B. decoratus (Jones) and B. miliaris Hiltermann and Koch are again recorded from lower Maestrichtian strata.

In northwest Europe the Maestrichtian Stage is subdivided into lower and upper substages and the distribution of key benthic taxa against this standard has been described by Swiecicki (1980). Unfortunately, the comparison of this bipartite division with the tripartite scheme adopted by workers on Tethyan planktonic foraminifers (Robaszynski et al., 1984) is not known in detail at the present time and this has caused some difficulties in the present investigation. As indicated earlier no "middle Maestrichtian" planktonic assemblage has been recorded by the author at Site 612 , and there are no benthic taxa that are characteristic of the upper half of the northwest European early Maestrichtian. Thus, although no definitive statements can be made, it seems that from both these lines of evidence the mid-Maestrichtian (based on foraminifers) is not represented in the Site 612 succession. The species used in Table 2 are now listed as follows:

Ammodiscus cretaceus (Reuss) = Operculina cretacea Reuss, 1845, p. 35 , pl. 13, figs. 64,65 .

Arenobulimina obliqua (d'Orbigny) = Bulimina obliqua d'Orbigny, 1840 , p. 40 , pl. 4 , figs. 7,8 .

Ataxophragmium variabile (d'Orbigny) = Bulimina variabilis d'Orbigny, 1840 , p. 40 , pl. 4 , figs. 9 , 10 , (11?, not 12$)$.

Bolivina incrassata Reuss, 1851, p. 45, pl. 4(5), fig. 13.

Bolivinoides decoratus (Jones) = Bolivina decorata Jones (in Wright), 1875 , pp. 87, 96, 97.

Bolivinoides laevigatus Marie, 1941, p. 189, pl. 29, fig. 281.

Bolivinoides miliaris Hiltermann and Koch, 1950, pp. 604-606, t. figs. $2-4$, nos. $32-34,39-41,46-48$, t. fig. 5 , no. 39.

Cibicides beaumontianus (d'Orbigny) = Truncatulina beaumontiana d'Orbigny, 1840, p. 35, pl. 3, figs. 17-19.

Dentalina gracilis d'Orbigny, 1840 , p. 14 , pl. 1, fig. 5 .

Dorothia pupa (Reuss) $=$ Textularia pupa Reuss, 1860, p. 232, pl. 13, figs. 4,5 .

Eouvigerina aculeata (Ehrenberg) = Loxostomum aculeata Ehrenberg, 1854 , p. 22 , pl. 27 , figs. 21,22 , pl. 28 , fig. 26.

Eponides beisseli Schijfsma, 1946, p. 84, pl. 4, fig. 13.

Eponides biconvexa Marie, 1941, p. 224, pl. 34, fig. 324.

Frondicularia arkadelphiana Cushman, 1946, p. 91, pl. 37, figs. 21, 22.

Gardryina pyramidata Cushman, 1926, p. 587, pl. 16, fig. 8a-b.
Gavelinella clementiana (d'Orbigny) = Rosalina clementiana d'Orbigny, 1840 , p. 37 , pl. 3 , figs. 23-25.

Gavelinella cristata $($ Goel $)=$ Pseudovalvulineria cristata Goel, 1965, p. 134 , pl. 8 , fig. 1 .

Gavelinella monterelensis (Marie) = Anomalina monterelensis Marie, 1941 , p. 243 , pl. 37 , fig. 342.

Gavelinella pertusa (Marsson) = Discorbina pertusa Marsson, 1878, p. 166 , pl. 4 , fig. 35 .

Globorotalites hiltermann Kaever, 1961, pp. 418-419, pl. 20, fig. 1.

Globorotalites micheliniana (d'Orbigny) $=$ Rotaline micheliniana d'Orbigny, 1840, pp. 31-32, pl. 3, figs. 1-3.

Globulina prisca Reuss, 1860, p. 79, pl. 9, fig. 8.

Gyroidinoides nitida (Reuss) $=$ Rotalina nitida Reuss, 1844, p. 214.

Haplophragmoides walteri $($ Grzybowski) $=$ Trochammina walteri $\mathrm{Gr}$ zybowski, 1898, p. 290 , pl. 11, fig. 31.

Hoeglindina $\mathrm{sp}$. (not identifiable from the material available).

Lenticulina spp. (a large number of species, but very few individuals from which to make specific determinations).

Loxostomum eleyi (Cushman) = Bolivinita eleyi Cushman, 1927, p. 91, fig. 11.

Marginulina elongata d'Orbigny, 1840, p. 17, pl. 1, figs. 20-22.

Marssonella conoidea (Marie) = Textularia conoidea Marie, 1941, p. 63 , pl. 2, fig. 20.

Marssonella ellisoriae Cushman, 1936, p. 44, pl. 4, fig. 11.

Marssonella trochus (d'Orbigny) = Textularia trochus d'Orbigny, 1840 , p. 45 , pl. 4 , figs. $25,26$.

Neoflabellina praereticulata Hiltermann, 1952, p. 53, t. fig. 3, fig. 37.

Neoflabellina rugosa (d'Orbigny) = Flabellina rugosa d'Orbigny, 1840 , p. 23 , pl. 2 , figs. $4,5,7$.

Nodosaria affinis Reuss, 1854, p. 26, pl. 13, fig. 16a-b.

Osangularia cordieriana (d'Orbigny) = Rotalina cordieriana d'Orbigny, 1840 , p. 33 , pl. 3, figs. 9-11.

Osangularia navarroana (Cushman) = Pulvinulinella navarroana Cushman, 1938, p. 66, pl. 11, fig. 5.

Pleurostomella subnodosa Reuss, 1860, p. 204, pl. 8, fig. 2.

Praebulimina laevis $($ Beissel) = Bulimina laevis Beissel, 1891, p. 66, pl. 12, figs. 39-43.

Praebulimina obtusa (d'Orbigny) = Bulimina obtusa d'Orbigny, 1840 , p. 39 , pl. 4 , figs. 5,6 .

Pseudouvigerina plummerae Cushman, 1927, p. 115, pl. 23, fig. 8.

Pullenia quaternaria (Reuss) = Nonionina quaternaria Reuss, 1851, p. 34 , pl. 2, fig. 13 .

Quadrimorphina allomorphinoides (Reuss) = Valvulina allomorphinoides Reuss, 1860 , p. 223 , pl. 11, fig. 6 .

Reussella szajnochae szajnochae (Grzybowski) = Verneuilina szajnochae Grzybowski, 1896, p. 287, pl. 9, fig. 19.

Spiroplectammina subhaerigensis (Grzybowski) = Textularia subhaeringensis Grzybowski, 1896, p. 285, pl. 9, figs. 13, 16.

Stenioeina exsculpta gracilis Brotzen, 1945, p. 52, pl. 1, fig. 15.

Stensioeina pommerana Brotzen, 1936, p. 166.

Vaginulinopsis scalariformis Porthault, in Donze et al., 1970, pp. 5152 , pl. 8 , figs. $1-2$, t. fig. 3a-b.

Verneuilina muensteri Reuss, 1854 , p. 71 , pl. 26, fig. 5. 


\section{REGIONAL IMPLICATIONS}

Recently Nyong and Olsson (1984) and Olsson and Nyong (1984) have documented the late Cretaceous palaeoenvironments of the New Jersey Coastal Plain and the adjacent offshore areas. From their palaeoslope model, they concluded that there was a transgressive event during the late Campanian, followed by a slight regression in the early Maestrichtian. They also describe the occurrence of a localized oxygen deficient zone within the late Campanian sediments of the New Jersey Slope.

As a part of the present investigation, faunal counts have been made on samples from Site 612 and calculated as percentages of keeled planktonic foraminifers, non-keeled planktonic foraminifers, calcareous benthic foraminifers, and arenaceous benthic foraminifers. The graph so produced (see Fig. 3) shows a quite distinctive change at the Campanian/Maestrichtian boundary as described earlier. The late Campanian assemblage contains a rich assemblage of arenaceous and calcareous benthic foraminifers, whereas above the hiatus the total benthic component of the fauna rarely climbs as far as $20 \%$ of the total.

Hart and Ball (1986) have recently documented the Upper Cretaceous succession (Fig. 4) at DSDP Site 551 (Goban Spur, northeast Atlantic Ocean). That succession again shows this reduced planktonic fauna in the late Campanian, with the benthic fauna in this example running as high as $95 \%$ of the total. Literature on Cretaceous transgressions/regressions (Hancock and Kauffman, 1979) indicate that over most of the globe there is a transgressive peak in the late Campanian. This would indicate that planktonic faunas should extend more widely at that time, and the lack of a diverse planktonic fauna at Sites 612 and 551 must clearly indicate some alternative environmental interpretation and possible restriction. Hart and Ball (1986) have interpreted the data from Sites 612 and 551 as indicating the presence of an oxygen-depleted zone in the water column during a period of eustatic highstand. Although such "oceanic anoxic events (OAEs)" are well documented in the Aptian/Albian, late Cenomanian and Santonian, this record in the late Campanian is quite interesting as it probably indicates that during the greater part of the late Cretaceous a layer of oxygendepleted water existed in a good part of the North Atlantic Ocean.

Previously described OAEs are only the intervals where the depleted zone expanded in the water column to the point where it could be detected by the limited number of sites that have penetrated this stratigraphic interval. Whenever this has occurred (e.g., the late Cenomanian event in northwest Europe) it is expressed by the widespread distribution of a grey-black mudstone, rich in dinoflagellates and with a significantly reduced fauna of planktonic foraminifers.

\section{SUMMARY}

The late Campanian and early Maestrichtian succession at Site 612 provides benthic faunas directly comparable with those in northwest Europe and serves to demonstrate how cosmopolitan the late Cretaceous fauna had

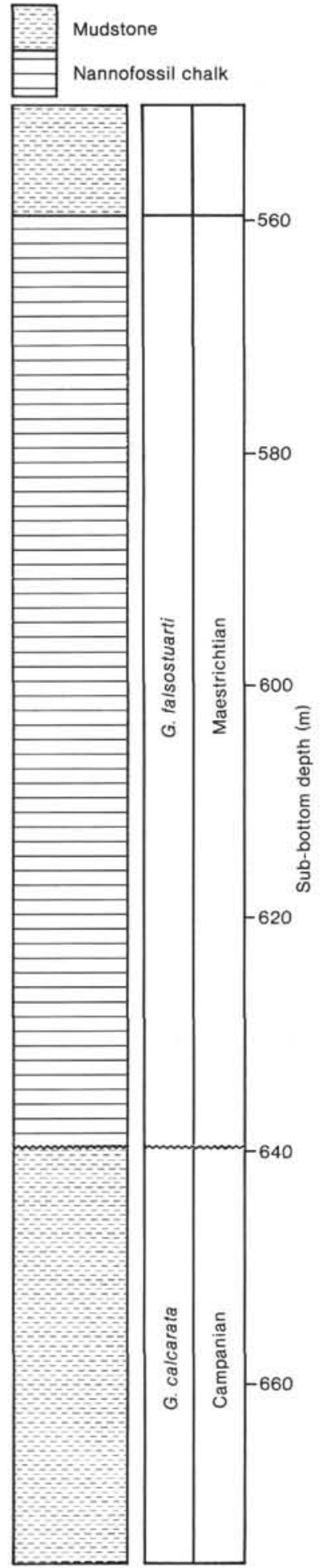

Figure 3. The Cretaceous succession at Site 612 is a mudstone-dominated late Campanian sequence overlain by a nannofossil chalk sequence of early Maestrichtian age. No data are presented for the overlying Cenozoic succession. The percentages plot of the foraminifers is based on counts of the $500-250 \mu \mathrm{m}$ size fraction and is subdivided into the following categories: (a) keeled planktonic foraminifers, (b) non-keeled planktonic foraminifers, (c) calcareous benthic foraminifers, and (d) arenaceous benthic foraminifers. 
(a)

(b)

(c) (d)
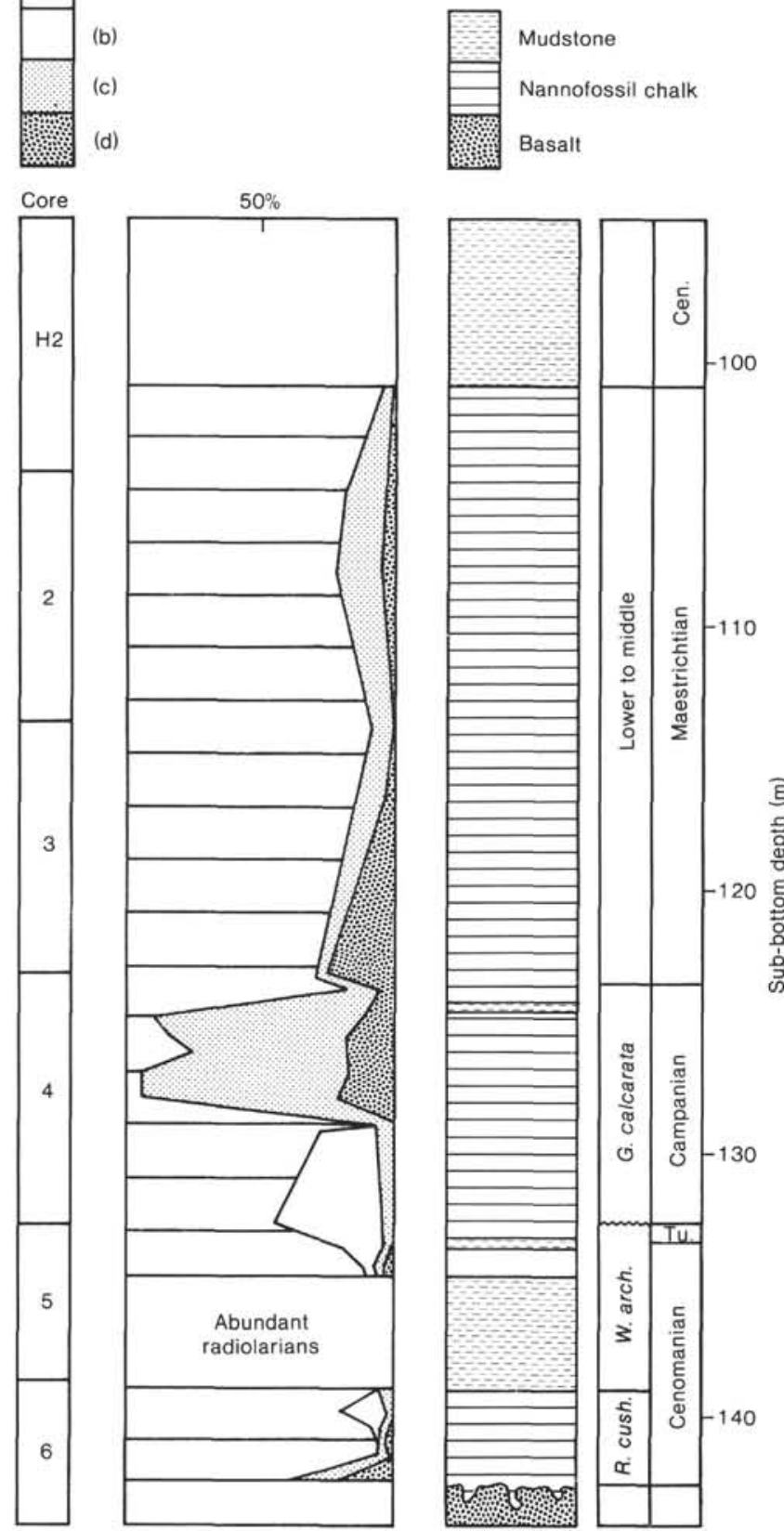

Figure 4. The Cretaceous succession at Site 551. The geological succession is complicated by the major hiatus between the early Turonian and the late Campanian. No data are presented for the overlying Cenozoic succession. The graph is based on the same categories as given in Figure 3. At Site 551, middle Maestrichtian is definitely proven but the boundary between the zones is yet to be established; this explains the use of the terms "lower" and "middle" instead of species names. $R$. cush. = Rotalipora cushmani, W. arch.$=$ Whiteinella archaeocretacea .

become. The presence of a localized anoxic "event" at Site 612 confirms the palaeoslope model of Nyong and Olsson (1984) and the predictions made by Hart and Ball (in press) in their study of the material from DSDP Leg 80.

\section{ACKNOWLEDGMENTS}

The author wishes to acknowledge the financial assistance given by the Natural Environment Research Council for participation on this leg. The other shipboard scientists are thanked for their assistance in the formulation of the ideas expressed in this chapter.

\section{REFERENCES}

Bailey, H. W., 1978. A foraminiferal biostratigraphy of the Lower Senonian of Southern England [unpublished Ph.D. thesis]. Plymouth Polytechnic/Council for National Academic Awards, Devon, United Kingdom.

Banner, F. T., and Blow, W. H., 1960. Some primary types of species belonging to the superfamily Globigerinacea. Contrib. Cushman Found. Foraminiferal Res., 11:1-41, pls. 1-8.

Beissel, L., 1891. Die Foraminifera der Aachener kreide. Abh. Preuss. Geol. Landesanst., 3:1-78.

Brönnimann, P., 1952. Globigerinidae from the Upper Cretaceous (Cenomanian-Maestrichtian of Trinidad, B.W.I. Bull. Am. Paleontol., 34:5-71.

Brotzen, F., 1936. Foraminiferen aus dem Schwedischen untersten Senon von Eriksdal in Schonen. Sver. Geol. Unders. Afh. C, 30: 1-206.

1945. De Geologiska Resultaten fran Borrningarna vid Höllviken-Preliminar rapport Del 1: kritan. Sver. Geol. Unders. Afh. C, pp. 1-64.

Carsey, D. O., 1926. Foraminifera of the Cretaceous of Central Texas. Texas Univ. Bull., 2612:1-56.

Cushman, J. A., 1926. Some foraminifera from the Mendez Shale of eastern Mexico. Contrib. Cushman Lab. Foram. Res., 2:16-26, pls. 2-3.

1927. An outline for a re-classification of the foraminifera. Contrib. Cushman Lab. Foram. Res., 3:1-105.

1936. New genera and species of the families Verneuilinidae and Valvulinidae and of the subfamily Virgulininae. Spec. Publ. Cushman Lab., Sharon, Mass., 1-71.

1938. Some new species of rotaliform foraminifera from the American Cretaceous. Contrib. Cushman Lab. Foraminiferal Res., 14:66-71, pls. 11-12.

1946. Upper Cretaceous foraminifera of the Gulf Coastal region of the United States and adjacent areas. U.S. Geol. Surv. Prof. Pap., 206:1-241.

Dalbiez, F., 1955. The genus Globotruncana in Tunisia. Micropaleontology, 1:161-171.

Donze, P., Porthault, B., Thomel, G., and Valloutrey, D., 1970. Le Sénonien inférieur de Puget-Théniers (Alpes-Maritimes) et sa microfauna. Geobios, 3:41-106, pls. 8-13.

Ehrenberg, C. G., 1840. Die Bildung der Europaischen, Libyschen und Arabischen Kreidefelesen und des Kreidemergels aus mikroskopischen Organismen. Abh. Preuss. Akad. Wiss. Phys. Math. Kl., 1-91. 1854. Mikrogeologie: Leipzig.

Gandolfi, F., 1955. The genus Globotruncana in northeastern Colombia. Bull. Am. Paleontol., 36:7-118.

Goel, R. K., 1965. Contributions à l'étude de Foraminiféres du Crétacé supérieur de la Baisse-Seine. Bull. Bur. Rech. Geol. Min., 5: 49-157.

Gryzbowski, J., 1896. Otwornice czerwonych ilow s Wadowic. Rozpr. Akad. Umiejet, Krakowie, 10:261-308, pls. 8-11.

1898. Mikroskopowe badznia namutow wierthiczych $z$ kopala naftowych. I. Pas potocki i okolice krosna, II. Uwagi ogolne. Kosmos, 22:393-439.

Hancock, J. M., and Kauffman, E. G., 1979. The great transgressions of the Late Cretaceous. J. Geol. Soc. London, 136:175-186.

Hart, M. B., Bailey, H. W., Fletcher, B. N., Price, R. J., and Swiecicki, A., 1981. Cretaceous. In Jenkins, D. G., and Murray, J. W., (Eds.), Stratigraphical Atlas of Fossil Foraminifera: Chichester, U.K. (Ellis Horwood), pp. 149-227.

Hart, M. B., and Ball K. C., 1986. Late Cretaceous anoxic events, sea level changes and the evolution of the planktonic foraminifera. Spec. Issue J. Geol. Soc. London.

Hiltermann, H., 1952. Stratigraphische Fragen des Campan und Maastricht unter besonderer Berucksichtigung der Mikropaläontologie. Jahrb. Geol. Landesanst., 67:47-66. 
Hiltermann, H., and Koch, W., 1950. Taxonomie und Vertikalvertbreitung von Bolivinoides - Arten im Senon Nordwesztdeutschlands. Jahrb. Geol. Landesanst., 70:357-384.

Kaever, M., 1961. Morphologie, Taxonomie und Biostratigraphie von Globorotalites und Conorotalites (Kreide-Foram). Jahrb. Geol. Landesanst., 78:387-438.

Klasz, I. de, 1953. Einige neue oder wenig bekannte Foraminiferen aus der helvetischen Oberkreide der bayerischen Alpen südlich Traunstein (Oberbayern). Geol. Bavarica, 17:233-244, pls. 4-7.

Lalicker, C. G., 1948. A new genus of Foraminifera from the Upper Cretaceous. J. Palaeontol., 22:624.

Marie, P., 1941. Les foraminiféres de la Craie á Belemnitella mucronata du Bassin de Paris. Mem. Mus. Nat. Hist. Nat. Paris, N. Ser., 12:1-296.

Marsson, T., 1878. Die Foraminiferen der weissen Schreibkreide der Inslen Rügen. Mitt. Naturwiss. Ver. Neu-Vorpomm., Berlin, 10: 115-196.

Naggar, Z.R.E. El, 1966. Stratigraphy and planktonic foraminifera of the Upper Cretaceous-Lower Tertiary succession in the Esna-Idfu Region, Nile Valley, Egypt, U.A.R. Brit. Mus. Nat. Hist. Bull. (Geol.), Supp., 2:1-291.

Nakkady, S., 1950. A new foraminiferal fauna from the Esna Shales and Upper Cretaceous Chalk of Egypt. J. Palaeontol., 24:675-692.

Nyong, E. E., and Olsson, R. K., 1984. A palaeoslope model of Campanian to Lower Maestrichtian Foraminifera in the North American Basin and adjacent Continental margin. Mar. Micropaleontol., 8:437-477.

Olsson, R. K., 1964. Late Cretaceous planktonic foraminifera from New Jersey and Delaware. Micropaleontology, 10:157-188.

Olsson, R. K., and Nyong, E. E., 1984. A Palaeoslope Model for Campanian-Lower Maestrichtian Foraminifera of New Jersey and Delaware. J. Foraminiferal Res., 14:50-68.

Orbigny, A. d', 1839. Foraminiféres. In de Sagra, R. (Ed.), Histoire Physique, Politique et Naturelle de l'Ile de Cuba: Paris (Cuba). 1840. Memoire sur les foraminiféres de la craie blanche du Bassin de Paris. Mém. Soc. Géol. France, 4:1-51.

Pessagno, E. A. Jr., 1960. Stratigraphy and micropalaeontology of the Cretaceous and lower Tertiary of Puerto Rico. Micropaleontology, 6:87-110.

1967. Upper Cretaceous planktonic foraminifera from the western Gulf Coastal Plain. Palaeontographica Americana, 37: $245-445$.

Plummer, H. J., 1926. Foraminifers of the Midway Formation in Texas. Texas Univ. Bull., 2644:1-206.

1931. Some Cretaceous foraminifera in Texas. Bull. Univ. Texas, Bur. Econ. Geol., Technol., 3101:109-203.

Poag, C. W., 1985. Cenozoic and Upper Cretaceous sedimentary facies and depositional systems of the New Jersey slope and rise. In Poag, C. W. (Ed.), Geologic Evolution of the United States Atlantic Margin: New York (Van Nostrand Reinhold), pp. 343-365.
Reuss, A. E., 1844. Geognostiche Skizzen aus Bohem (Vol. 2): Prague.

1846. Die Versteinerungen der böhmischen Kreideformation. Stuttgart, 2, 1-148.

1851. Die Foraminiferen und Entomostraceen des Kreidemergels von Lemberg. Abh. Naturwiss. Wien, 4:17-52.

1854. Beitrage zur Characteristik der Kreideschichten in dem Ostalpen, besonders in Gosauthele und am Woldgangsee. Denkschr. Akad. Wiss. Wien, 7:1-156.

1860. Die Foraminiferen Westphalischen Kreideformation. Sber. Akad. Wiss. Wien, 40:147-238.

Robaszynski, F., Caron, M., Gonzalez Donoso, J. M., and Wonders, A. A. H., 1984. Atlas of Late Cretaceous Globotruncanids. Rev. Micropaleontol., 26:145-305.

Rzehak, A., 1891. Die Foraminiferenfauna der altertiären Ablagerungen von Bruderndorf in Niederösterreich, mit Berücksichtigung des angleblichen Kreidevorkommens von Leitzersdorf. Ann. Naturhist. Mus. Wien, 6:1-12.

Schijfsma, E., 1946. The Foraminifera from the Hervian (Campanian) of Southern Limburg, Netherlands. Meded. Geol. Sticht. Nieuwe Ser. Neth. C5.

Sigal, J., 1952. Aperçu stratigraphique sur la Micropaléontologie du Crétacé. Int. Geol. Congr., 19th, Mongr. rég., 1st Ser., Algérie, 26:1-45.

Sliter, W. V., 1968. Upper Cretaceous foraminifera from southern California and northwestern Baja California, Mexico. Univ. Kans. Palaeontol. Contrib., Protozoa, 49(7):1-141.

Smith, C. C., and Pessagno, E. A. Jr., 1973. Planktonic foraminifera and stratigraphy of the Corsicana Formation (Maestrichtian), North-Central Texas. Contrib. Cushman Found. Foraminiferal Res., Spec. Publ., 12:1-68.

Swiecicki, A., 1980. A foraminiferal biostratigraphy of the Campanian and Maastrichtian chalks of the United Kingdom [Unpublished Ph.D. thesis]. Plymouth Polytechnic/Council for National Academic Awards, Devon, United Kingdom.

Tilev, N., 1951. Etude des Rosalines maesstrichtiennes (genre Globotruncana) du Sud-Est de la Turquie (sondage de Ramandag). Lausanne Univ. Lab. Géol. Minéral Géophys. Mus. Géol. Bull., 103: 1-101.

Vogler, J., 1941. Ober-Jura und Kreide von Misol. In Boehm, G., and Wanner, J., (Eds.), Beitrage zur Geologie von Niederlandisch-Indien. Palaeontographica, Suppl., 4:243-293.

Voorwijk, G. H., 1937. Foraminifera from the Upper Cretaceous of Havana, Cuba. K. Ned. Akad. Wet. Proc., Ser. B, 40:190-198.

White, M. P., 1928. Some index foraminifera from the Tampico Embayment area of Mexico. J. Paleontol., 2:280-317.

Date of Initial Receipt: 5 August 1985

Date of Acceptance: 31 January 1986 

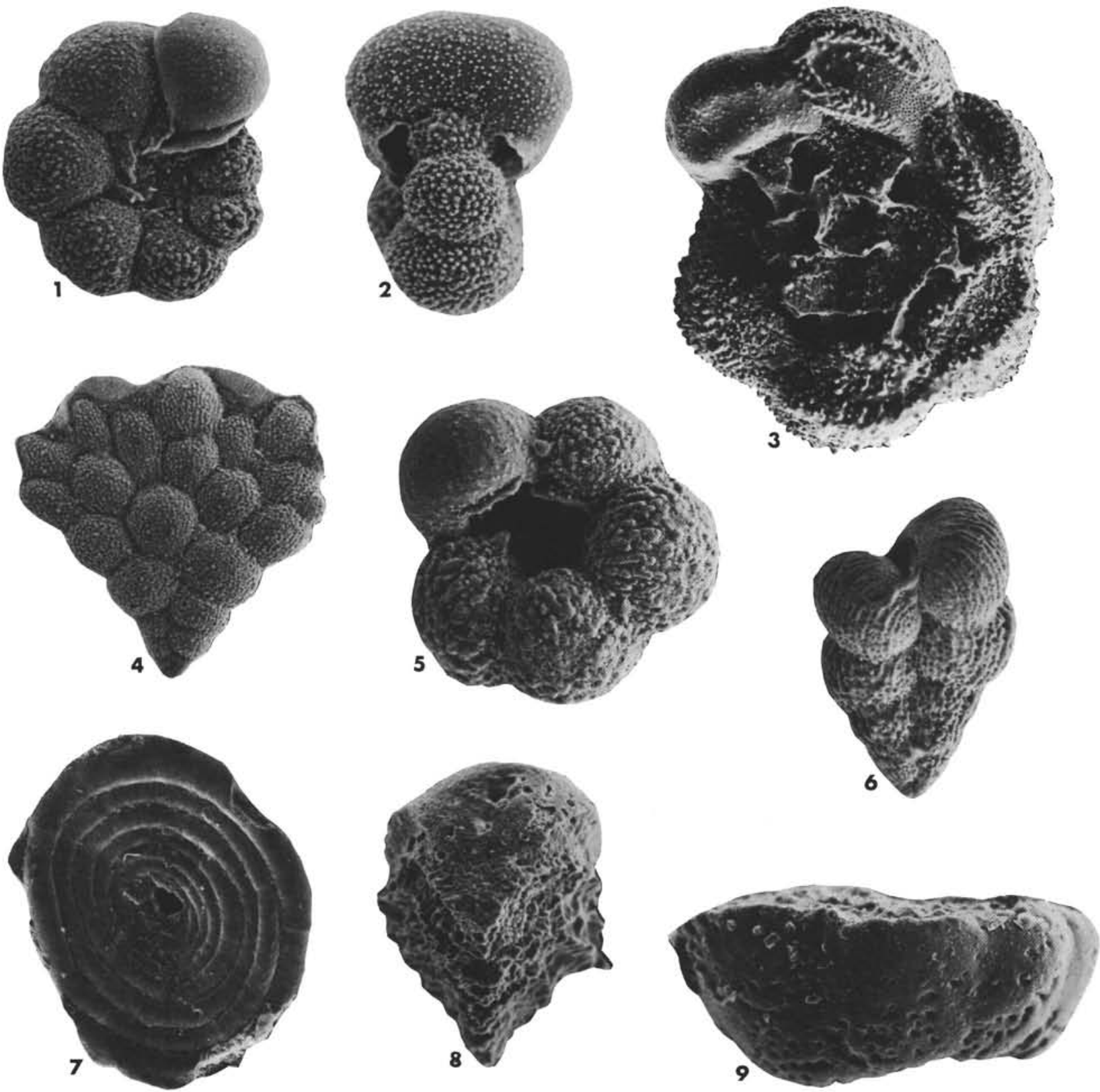

Plate 1. 1, 2. Globigerinelloides multispina (Lalicker), Sample 612-65,CC, early Maestrichtian, ( $\times 100)$. 3. Globotruncana arca (Cushman), Sample 612-63,CC, early Maestrichtian, $(\times 150)$. 4. Planoglobulina multicamerata de Klasz, Sample 612-62,CC, early Maestrichtian, $(\times 150)$. 5. Rugoglobigerina pennyi Brönnimann, Sample $612-61-4,30-32 \mathrm{~cm}$, early Maestrichtian, $(\times 120)$. 6. Heterohelix striata (Ehrenberg), Sample $612-66, C C$, early Maestrichtian, $(\times 250)$. 7. Ammodiscus cretaceus (Reuss), Sample $612-71, \mathrm{CC}$, late Campanian $(\times 100)$. 8. Reussella szajnochae szajnochae (Grzybowski), Sample 612-72,CC, late Campanian, $(\times 100)$. 9. Stensioeina pommerana Brotzen, Sample 612$69, \mathrm{CC}$ late Campanian, $(\times 150)$. 